\title{
ALGUNOS CUENTOS DE ROSSI
}

\author{
POR
}

José BALZA

Pareciera como si a mediados de los ochenta a Alejandro Rossi le hubiese ocurrido un extraño suceso: su conversión en cuentista puro o en el cuentista de las regiones.

Antes, lo sabemos, había sido el autor de Lenguaje y significado, del legendario Manual del distraído, de Sueños de Occam. Caracterizar cada una de tales publicaciones exigiría páginas que no son éstas; en las dos últimas, sin embargo, se agiliza una elegante desobediencia a los cánones: con ellas afrontaremos ensayos, reflexiones, anotaciones que no temen mezclarse o ser plieges de la anécdota o de la abstracción. También en ellas se nos invita deliberadamente a leer "con amor al detalle".

Es ya reconocido y ocupa un fulgurante espacio en la prosa del continente, el pulso literario de Alejandro Rossi: como pudieran mostrarlo otros escritores afines a él (Julio Garmendia en Venezuela, Julio Torri en México, Franz Tamayo en Bolivia, Borges), hay algo de rayo y de compasivo en su estilo, sin que esto omita profundidad e ironía.

Milagrosamente (o debido a esa segunda naturaleza que pervive en un escritor) es dentro de esa prosa idéntica que se produjo la situación.

Quien relea los más narrativos textos de Sueños de Occam no solamente reirá con los despiadados retratos de algunos personajes o asumirá el desconcierto ante matices propuestos por el autor a la realidad más nimia, sino que notará la circulación de dos recursos opuestos. En primer lugar, la manera como ciertos elementos marcan con fuerte trazo los pivotes materiales para la fluidez de lo narrable. Veamos entonces la eficacia del sillón de tela, la bata escocesa, los calcetines verde botella, el brazo, el cigarro, la mostaza (en En plena fuga) o Da Silva un muchacho no verbalizado y su famosa madriguera de lujo (en Entre amigos); y aun el silbido, los diez o doce pasos, la camisa de popelina azul, el calzador de hueso en Sueños de Occam. Tan precarios y a la vez eficaces ingredientes sostienen la trama y producen una frotación de sentidos; la perfección del relato, sin embargo, los hunde, los escamotea, precisamente porque han sido toques para desatar la significación. El lector los olvidará para poder desandar o revelarse las implicaciones conceptuales, filosóficas del tramado - no de la anécdota.

Por otra parte, el libro ajusta frases que, de manera rara, parecieran ser paralelas, por su grado de invisibilidad, a los componentes anteriores. Colocadas de manera indirecta respecto de la acción, cosas como "los buenos cuentos, me han dicho, comienzan en un lugar definido" o "valdría la pena fundir esos enérgicos materiales en un solo cuento" son 
guardadas con discreción por el discurso. Así, una tercera dirección se sumó a las ya sugeridas; y ésta parecía recoger una intuición del escritor, que por entonces sólo se asomaba al guiso anecdótico. Cuando el libro se publica estamos en 1983; no en vano en un relato tan neurálgico como Sueños de Occam alguien piensa "con euforia de inventor, cómo mejorar ciertos movimientos de mi vida".

¿Mejoría o diferencia dentro de la unidad verbal? En 1988 Rossi da a conocer $L a$ fábula de las regiones, un volumen con tres cuentos, inventados como otro movimiento de una misma imaginación.

El cambio ha sido consumado. Ahora, a través de imágenes e historias, nos hemos alejado de Gracián y de Lichtenberg; pero quizá comenzamos a estar cerca de José de la Cuadra, de García Márquez y de Shakespeare (en lo que cada escena suya tiene de cuento y de vitral). El Rossi filósofo desatiende (no olvida) la intensidad aforística para que su voz se entregue con "amor al detalle".

No es que haya concluido el misterio de Manual del distraido sino que, al hacer uso de palabras "serpentinas", se puede abarcar un "espacio definido" para la mise en abîme. Dicho de otra manera, ya Juan Nuño, en su prólogo a la edición venezolana del Manual, había detectado "el extraño resplandor de lo brevemente observado mientras se atiende a los grandes negocios de la existencia". Si la precisión conceptual fulguraba en la brevedad del pensamiento, ahora lo observado se demora como anécdota, ya que todo eje temporal de un cuento sólo existe en aquello que lo encarna, un "espacio definido": en el desarrollo o la ampliación de mínimas pistas y señas, en situaciones.

Un "latido de las regiones": éste podría ser el hilo conductor para la invención del ámbito: porque "en esas tierras de soles lentos todo se volvía intercambiable y anónimo". Como "descosidas regiones", poseen una "Ciudad carcomida por el salitre y cargada de viejos cocoteros", a la vez que hay pueblos sobre montañas y "dificultades de vivir junto a las grandes aguas". Hay gente del Puerto que se entromete en la zona y sectas que pasan $y$ un frecuente uso de hamacas ("color de espiga") y de guayaberas.

Ambiguo, cálido, remoto, memorioso y a la vez extenso, importante para el poder actual, vivo en su solar, cualidad de vitral, el espacio de estos relatos es uno de sus protagonistas principales. Su aura de siesta, de lasitud no excluye el peligro, la ambición, el erotismo. Alejandro Rossi está leyendo como desde el olvido los ámbitos salvajes de José Eustasio Rivera y de José de la Cuadra; sólo que el tono crepuscular de los viejos guerreros rossianos tamiza lo épico en desamparo. (Tal vez un crítico que también ejerza la pesquisa biográfica podría detectar aquí, en el autor, la reverberación en que se imbrican una historia familiar —el general Paéz en los llanos venezolanos — y mural — la revolución mexicana, sus vestigios.

Tanto en El cielo de Sotero como en La estatua de Camargo el tema primordial apunta hacia la política y el poder, el sacrificio, la astucia y la destrucción, sin omitir su otra cara: la inocencia, la inconciencia, la dudosa mitología popular. En el primer relato, un agudo manejo de lo elíptico conduce al protagonista hacia la muerte y hacia su propia negación; en el otro (hábilmente trazado por recurso teatral: el diálogo), un hombre con "esa vaga hermosura de los hombres que no han decidido aún su vida" es llevado por el uso colectivo al sacrificio. 
En el último texto, Sedosa, la niña, ese mismo tema asciende gradualmente, pero matizado por la percepción del protagonista, el "general" (uno de los "cuatro viejos muertos de aburrimiento"). Al parecer la guerra, todo, ha pasado, pero allí arrinconados, los varones fluviales advierten siempre la amenaza del poder, del cambio; de algún modo han pertenecido a la "utopía agraria pre-industrial". El relato se diferencia notablemente de los anteriores porque su composición descansa en el prolongado monólogo (o discurso histórico) del viejo, que de algún modo resume un pasado implícito en los otros cuentos ("Ya no somos héroes, más bien una jerigonza incomprensible"); también porque en él las muchachas de placer, "tan afamadas en esas zonas fluviales", húmedas y pacientes, alcanzan plenitud en Marielita (la sedosa niña).

"Sospecho que cuando comprendemos el amor que una persona suscita en otra, ya nos entregamos a ella", se nos había dicho en Sotero y el abuelo en la historia de Sedosa ha traído para su nieto de catorce años una chica de "cruza reciente": "No la atropelles, acércate cuando se haga la dormida, cuando esté bien tibia", le enseñó.

Ahora es el viejo quien aprovecha la ausencia del nieto para amar a Sedosa. "Nunca entramos solos al amor, están con nosotros quienes nos precedieron, genealogías iluminadas y obscuras cuyo origen exacto ignoramos. Es una carga de caballería, nunca un duelo solitario". Que también incluye el presente y hasta el futuro, como lo evidencia la lenta y prolongada posesión con que el viejo invade a la niña. En secreto, en silencio ("Ya tendrás tiempo de irte con él. Nosotros casi terminamos"), el general vence en sus últimas batallas.

Una media docena de vocablos (las regiones, la guerra, el valor, un joven, etc.; en vez de los calcetines verde botella, por ejemplo) absorbe como intrigantes monedas el repertorio del autor. Lo que en sus otros libros hubiese pervivido bajo el ingenio, toma aquí cualidades terrenas. Algo resta, sin embargo, del primer Rossi; sólo que ahora la sustancia verbal se ha untado de tal manera a lo anécdotico, que no parece necesitar autonomía. El pensamiento pasa a ser imagen completamente. numerosas reflexiones, observaciones y atisbos sobre el montaje del cuento se escurren en medio de las fábulas. El lector interesado en tales tópicos los hallará con gusto. Pero en el relato inicial, una ambigua frase todo lo camufla: "El nombre no podía ser más común". 
